\title{
A comparison of the value relevance of interim and annual financial statements
}

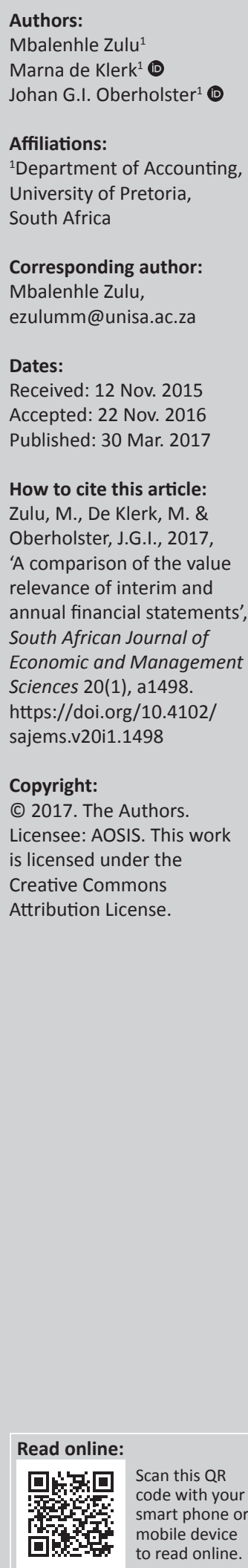

Background: This study tests the value relevance of interim accounting information. The study also explores whether the value relevance of annual and interim financial statements has changed over time.

Aim: It explores whether the value relevance of interim financial statements is higher than the value relevance of annual financial statements. Finally, it investigates whether accounting information published in interim and annual financial statements has incremental value relevance.

Setting: Data for the period from 1999 to 2012 were collected from a sample of non-financial companies listed on the Johannesburg Stock Exchange.

Method: The Ohlson model to investigate the value relevance of accounting information was used for the study.

Results: The results show that interim book value of equity is value relevant while interim earnings are not. Interim financial statements appear to have higher value relevance than annual financial statements. The value relevance of interim and annual accounting information has remained fairly constant over the sample period. Incremental comparisons provide evidence that additional book value of equity and earnings that accrue to a company between interim and annual reporting dates are value relevant.

Conclusion: The study was conducted over a long sample period (1999-2012), in an era when a technology-driven economy and more timely reporting media could have had an effect on the value relevance of published accounting information. To the best of our knowledge, this is the first study to evaluate and compare the value relevance of published interim and annual financial statements.

\section{Introduction}

Dontoh, Radhakrishan and Ronen (2004) state that there is a commonly held view that annual financial statements have lost their value relevance because of a shift from a traditional-based economy to a highly technological economy. Earlier studies conducted in a traditional-based economy already provided some support for this notion, suggesting that annual financial statement information is not a timely reporting medium (Ball \& Brown 1968), and that interim reports pre-empt some of the information in the annual report (McNichols \& Manegold 1983). Thus, our overall objective is to evaluate and compare the value relevance of annual and interim accounting information. We develop three distinct objectives with different hypotheses to achieve our overall objective.

Accounting information is value relevant if it has a predicted association with market value of equity (Barth, Beaver \& Landsman 2001; Francis \& Schipper 1999). Most prior research has tested the value relevance of accounting information using annual data instead of interim data (sixmonthly or quarterly data). Yee (2004:2) indicates that academic research into interim reporting is 'surprisingly sparse'. This appears to be true. Examples of studies that use annual financial statement information to test for value relevance include the following: Chen and Zhang (2007), Clarkson et al. (2011), Collins, Maydew and Weiss (1997), Dimitropoulos and Asteriou (2008), Filip and Raffournier (2010), Francis and Schipper (1999), Hellstrom (2006), Liu and Liu (2007) and Venter, Emmanuel and Cahan (2014). Compared to the above, no prior study could be found that examines the value relevance of interim financial statement information. Four related studies used either a survey design (Taylor 1965) or focused on quarterly earnings announcements with an event study methodology (Brown \& Niederhoffer 1968; Opong 1995; Vieru, Perttunen \& Schadewitz 2006). The above-mentioned studies only tested the value relevance of annual 
financial statements and did not control for the value relevance of financial statements at interim reporting date; thus, we argue that the value relevance of annual financial statements can be a function of the value relevance of interim financial statements. It is this gap in the accounting literature that the study attempts to fill in. Given the extensive evidence provided in prior research of the value relevance of annual financial statement information, our first objective is to investigate the value relevance of interim financial statement information (earnings and book values of equity).

The second objective is to explore whether the value relevance of interim financial statement information and annual financial statement information has changed during the sample period. There are a number of studies that use annual accounting information to test for a change in value relevance and they provide mixed results, for example, Gjerde, Knivsfla and Saettem (2011), Goodwin and Ahmed (2006) and Thinggaard and Damkier (2008). Relevant to this study is the study by Landsman and Maydew (2002), who evaluated the changes in the value relevance of quarterly earnings announcements (not interim financial statements) using data from the 1980s. Hence, our study is the first study to investigate the changes in the value relevance of interim accounting information.

The third objective of this study is to investigate if accounting information in interim and annual financial statements is incrementally informative. Early studies suggest that the annual report is not always a timely communication medium and that quarterly interim reports may allow investors to pre-empt some of the information in the annual report (Ball \& Brown 1968; Firth 1981; Rippington \& Taffler 1995; Shores 1990). Similarly, McNichols and Manegold (1983) conclude that the marginal information content of an annual report is greater when it is not preceded by an interim report. Following Biddle, Seow and Siegel (1995), incremental comparisons are relevant when one or more accounting measures are taken as given and, thus, where it is necessary to assess the incremental contribution of the measures (also see Venter et al. 2014). We argue that incremental comparisons are relevant to both book value of equity and earnings. We argue that although book value of equity is measured cumulatively at a specific point in time (cumulative value at reporting date in either the interim financial statements or the annual financial statements), it is possible that companies are considering measurement issues relevant to property, plant and equipment and other assets more at annual reporting date than at interim reporting date. Reported earnings figures represent earnings for a specific period (in the context of this study, either for the 6-month period ending at the interim reporting date or the 12-month period ending at the annual reporting date). We argue that incremental comparisons between interim earnings and additional earnings that accrue to a company between interim and annual reporting dates are relevant to the study. There is currently no prior evidence on the incremental value relevance of earnings and book values of equity reported in interim and annual financial statements.
Thus far, no previous study could be found that has examined the value relevance of interim accounting information. Our study is also the first to investigate changes in the value relevance of interim accounting information, if any. We also contribute to the debate regarding changes in the value relevance of annual accounting information. Finally, to the best of our knowledge, this is the first study to test the incremental value relevance of interim and annual accounting information.

We use the available data of all non-financial listed companies on the Johannesburg Stock Exchange (JSE) for the period 1999-2012 to test our hypotheses. The JSE is the largest stock exchange in Africa with a market capitalisation of R10.5 billion on 31 December 2014 (JSE 2014), thus making the results relevant to the global economy and investors interested in investing in a South African company. According to the Global Competiveness Report, issued by the World Economic Forum (2015), the JSE compares well with some of the largest stock exchanges in the world in terms of market efficiency. The JSE requires all listed companies to publish interim financial statements on a six-monthly basis (JSE 2012). Our sample enables us to test the value relevance of accounting information for small and large companies in an efficient market (also see Prather-Kinsey 2006).

Using the Ohlson (1995) model as a basis, the results show that interim accounting information has a higher explanatory power for market value of equity than annual accounting information (88.2\% compared to $52.5 \%$ ). The results also show that the value relevance of both interim and annual accounting information has remained fairly constant over the sample period, except for the years 2006 and 2007 where there was a structural break in the relationship between market values of equity and book values of equity and earnings. Incremental comparisons provide evidence that book value of equity at interim reporting date has a positive and significant association with market value of equity, and the movement in book value of equity between the interim and annual reporting date has a positive and significant association with market value of equity. Incremental comparisons between interim earnings and earnings that accrue to a company between interim and annual reporting dates show that interim earnings are not value relevant in comparison with additional earnings that are value relevant. The results are robust when loss-companies are eliminated from the sample as well as for alternative specifications of the regression models used.

The results of the study will be of interest to investors when considering financial statement information for purposes of investment decision-making, and preparers of financial statements when considering the cost-benefit decisions regarding the level of detail to be disclosed or recognised in interim reports. The results may also be of interest to standard setters and regulatory bodies as the results show that additional book value of equity and additional earnings which accrue to a company between interim and annual reporting dates are value relevant. Finally, the results will be of interest to accounting academics interested in the value relevance of published financial statements. 
The remainder of this article is organised as follows: The next section provides study backgrounds, while the 'Prior literature and hypotheses development' section reviews the relevant prior literature and states the hypotheses. The 'Research method' section describes the sample selection procedure, data and research method used. The 'Results' section presents the results of the study and the 'Conclusion' section concludes the article.

\section{Background to the study}

Prior research on the value relevance of accounting information published in annual financial statements, conducted in different settings (e.g. International Financial Reporting Standards (IFRS) adoption countries versus countries where locally developed generally accepted accounting practices were applied, common versus code law countries, etc.), provides evidence that annual accounting information is value relevant to market participants (see Barth et al. 2001; Cahan et al. 2000; Clarkson et al. 2011; Collins et al. 1997; Devalle, Onali \& Magarini 2010; Dontoh et al. 2004; Filip \& Raffournier 2010; Francis \& Schipper 1999; Gjerde et al. 2011; Goodwin \& Ahmed 2006; Hellstrom 2006; Holthausen \& Watts 2001; Kothari 2001; Prather-Kinsey 2006; Thinggaard \& Damkier 2008). Not much prior research has been conducted on the value relevance of interim accounting information. Prior literature on the value relevance of interim accounting information is discussed in the next section.

The JSE listing requirements mandate the publication and distribution of interim reports 'after the expiration of the first six-month period of a financial year, by no later than three months after that date'. International Accounting Standard (IAS) 34, Interim Financial Reporting, applies when an entity prepares an interim financial report; it was issued in June 1998 and is operative for periods beginning on or after 01 January 1999. South Africa formally adopted IFRS in 2005 and interim reports are prepared in accordance with IAS 34. Prior to 2005, interim financial statements were prepared in accordance with the South African Accounting Standard AC 127, Interim Financial Reporting, which was almost identical to IAS 34 (Oberholster 2014).

\section{Prior literature and hypotheses development}

\section{Value relevance of interim financial statements}

Previous literature summarised in the 'Background to the study' section provides extensive evidence that accounting information published in annual financial statements is associated with share prices or market value of equity. In comparison, little research has been conducted using interim accounting information. Taylor (1965) published one of the early studies on the usefulness of interim reports. He surveyed the United States' financial analysts on the usefulness of the interim report and its ability to provide information that may affect share price and found that over $84 \%$ of the analysts indicated a strong positive feeling regarding the usefulness of such a report. Another early study conducted by Brown and Niederhoffer (1968) provided evidence that quarterly earnings as conveyed by the interim report are useful as a predictor of annual earnings. These studies suggest that interim reports can be useful for investors but do not show if the information contained in the reports is associated with market values of equity. In addition, Opong's (1995) event study investigated whether a public release of an interim financial report in the United Kingdom led to a share price reaction on the day of release. The study found that interim accounting information has information content that leads to a share price reaction on the day of the release. Our study however does not focus on the release of interim accounting information and the effect on share prices; rather, it focuses on the association of interim accounting information published in interim financial statements with share prices - it is an association study. Another study by Vieru et al. (2006) investigated investors' trading behaviour around interim earnings announcements and found that trading increased before the interim earnings announcement. Quarterly or interim earnings announcements have also been found to be associated with higher share price volatility (Alegria, McKenzie \& Wolfe 2009). Rahman et al. (2007) examined the advantages and disadvantages of quarterly reporting in a voluntary setting and found that quarterly reports are associated with higher analyst following and higher share price volatility.

Based on the prior literature that shows that interim reports and interim earnings announcements are associated with share prices and higher share price volatility on the day of release, we expect there to be an association between market values of equity and interim earnings and book values of equity; hence, the first hypothesis is stated as follows:

H1: Interim earnings and book values of equity (published in interim financial statements) are associated with market values of equity.

Prior literature as described in the 'Background to the study' section provides evidence that annual reported earnings and book value of equity are associated with market value of equity. A study by Prather-Kinsey (2006) found that on the JSE, annual earnings and the book values of equity are value relevant in explaining share prices. That study used data for the years 1998-2000 when South Africa was still moving towards convergence with IFRS. In contrast, this study cuts across both the pre-IFRS adoption period (1999-2004) and the post-IFRS adoption period (2005-2012), as it is possible that the association between annual accounting information and the market value of equity may have changed over time. With our overall objective in mind, we evaluate in an additional test whether this holds true over our extended sample period.

\section{Changes in the value relevance of annual and interim financial statements over time}

The increased use of technology has made it possible for users of financial statements to have access to information on a timelier basis. Following Dontoh et al. (2004), there is a 
commonly held view that annual financial statements have lost their value relevance because information is now more readily available than it used to be. Previous empirical research provides mixed results on whether the value relevance of annual accounting information has changed over time. Previous research was conducted in different countries, used different (and often much earlier) sample periods, and yielded mixed results. The results range from a decline in value relevance to an increase in value relevance. Previous studies are discussed in more detail below.

Firstly, one group of studies shows a decline in the value relevance of the annual accounting information over time. These studies examine the value relevance of earnings, book values of equity and change in the value relevance of earnings and book values of equity, and view the $R^{2} s$ as a reflection of value relevance (Brown, Lo \& Lys 1999; Dontoh et al. 2004; Lev \& Zarowin 1999). These studies show that the value relevance of accounting information has declined over time. Secondly, one study by Thinggaard and Damkier (2008) reports no change in the value relevance of annual accounting financial information over time. The study investigated whether the financial statement information became less value relevant in Denmark in the period from 1982 to 2000. Thirdly, another group of studies suggest that the value relevance of annual financial information has increased over time. Gjerde et al.'s (2011) study investigated the changes in the value relevance of financial reporting in Norway during the period from 1995 to 2004 and reported an increase in the value relevance. Hellstrom (2006) examined the value relevance of accounting information in Czech Republic during the period 1994-2001. Using an adjusted $R^{2}$ as a measure of value relevance, the study found that the value relevance has increased during the sample period. Furthermore, Goodwin and Ahmed's (2006) study investigated the value relevance of earnings and book values of equity over time in Australia during the period from 1975 to 1999. Comparing $R^{2}$ s, their results show that the value relevance of both earnings and the book value of equity have increased. Lastly, it has been argued that the value relevance of the accounting data in Europe after the introduction of the IFRSs strengthened as a consequence of adopting the IFRSs (Devalle et al. 2010).

Based on the prior literature that provides a range of mixed results on the changes in the value relevance of the annual accounting information, this hypothesis is stated in its null form as follows:

H2(a): The association of reported annual earnings and book values of equity with market values of equity has not changed over the sample period.

Landsman and Maydew (2002) used Beaver's (1968) abnormal trading volume and abnormal return volatility to examine the changes in the information content of quarterly earnings announcements over the period 1972-1988. Using a random sample of 108000 firm-quarter observations, they reported that the informativeness of quarterly earnings announcements increased over time. Landsman and
Maydew's (2002) study is different from our study as that did not empirically test the changes in the value relevance of interim accounting information published in interim financial statements but only tested the changes in the value relevance of quarterly earnings announcements. Hence, our study is the first to investigate the changes in the value relevance of interim accounting information published in interim financial statements. Because of the lack of prior literature that investigates the changes in value relevance of interim accounting information, the next hypothesis is stated in its null form as follows:

H2(b): The association of reported interim earnings and book values of equity with market values of equity has not changed over the sample period.

No prior study has compared the value relevance of interim financial statements with that of annual financial statements although some studies suggest that such a hypothesis might hold true. For example, an early work by Ball and Brown (1968) shows that the annual income report is not a timely medium because $85 \%-90 \%$ of its content is captured by more prompt media which may include interim reports. Similarly, an early study conducted by McNichols and Manegold (1983) also suggests that interim financial reports pre-empt some of the information contained in annual reports and thus reduce the informativeness of annual reports. In addition, Shores (1990) reports on the association between the interim information and security returns around the earnings announcement dates using a sample of firms whose securities trade over-the-counter over a period of 1 year (1983-1984). He shows that the amount of information content of annual earnings announcement is negatively associated with the level of interim information, while the extent of pre-emption of that information content is positively associated with the level of interim information. Following this line of arguments, the next hypotheses are stated as follows:

H2(c): Interim earning and book values of equity have a stronger association with market values of equity than annual earnings and book values of equity over the sample period.

\section{Incremental value relevance of accounting information in interim and annual financial statements}

Firth (1981) conducted an early event study on the information content of financial results and argues that the interim report has information content as a result of it being timelier than the annual report. Rippington and Taffler (1995) confirm Firth's (1981) findings, stating that the interim report is more useful to investors than the annual report. If six-monthly reported interim earnings pre-empt the annual earnings and are useful to the markets as indicated by earlier research, we expect interim earnings to be associated with market value of equity. In addition, we would expect earnings which accrue to a company between interim and annual reporting period not to be associated with market value of equity. However, it is also possible that a six-monthly interim report does not allow an investor to pre-empt annual earnings as well as quarterly earnings. In this case, we would expect additional 
earnings to be associated with market value of equity measured at financial year end. We argue that the same concepts are relevant to book value of equity at interim reporting date and the movement in book value of equity from interim reporting date to annual reporting date. If interim book values represent to a large extent the book values at financial reporting date, then they would be positively and significantly associated with market value of equity at year end, and the movement between book value of equity from interim reporting date to annual reporting date would not be value relevant. However, if this is not the case, the movement in book value of equity between these two dates would be value relevant, that is, associated with market value of equity. The hypothesis is developed to test whether interim financial statements and annual financial statements contain value relevant information incremental to each other and is stated as follows:

H3: Accounting information (earnings and book values of equity) in interim financial statements as well as the changes in these values between interim and annual reporting dates are (are not) associated with market value of equity at financial year end.

\section{Research method \\ Data and sample selection}

We began our sample selection with 367 listed or dual-listed companies on the JSE mainboard with company data on the McGregor BFA Database (as per the report downloaded from the McGregor BFA Database on 11 June 2014). All the required data (i.e. annual, interim financial statements and share price data) are available from the McGregor BFA Database. Following prior research, we excluded 69 financial companies because the nature of their financial ratios is different from other companies. We further excluded 40 companies which were listed on the JSE during 2011 and 2012 as these companies did not have published annual and interim financial statements during the sample period. This yielded a potential sample of 258 companies. From a potential sample of 3612 observations (258 companies*14 years), we lost some observations because of the fact that some companies had a shorter listing period, that is, listed during the sample period or delisted during the sample period (we do not eliminate companies with shorter listing periods - sample companies are required to have one financial year where both an interim and an annual report were published). A final sample of 2296 annual and interim observations has been used in our analysis, with a total of 4592 observations for our pooled analysis. Table 1 shows the sample composition. The Industrial sector has the most representation (30.6\%) in our sample, followed by the Basic materials sector with $26 \%$ and the Consumer services sector with $16.7 \%$ of the total number of companies included in the sample.

\section{Method}

\section{Value relevance of interim financial statements}

Previous research using the Ohlson (1995) model provides evidence that accounting information (book value and earnings) in annual financial statements (see the Background
TABLE 1: Sample composition

\begin{tabular}{lcc}
\hline Industry & $\boldsymbol{N}$ & $\mathbf{\%}$ \\
\hline Oil and gas & 4 & 1.6 \\
Basic materials & 67 & 26.0 \\
Industrials & 79 & 30.6 \\
Consumer goods & 30 & 11.6 \\
Health care & 7 & 2.7 \\
Consumer services & 43 & 16.7 \\
Telecommunications & 5 & 1.9 \\
Utilities & 1 & 0.4 \\
Financials & 0 & 0.0 \\
Technology & 22 & 8.5 \\
\hline Total & $\mathbf{2 5 8}$ & $\mathbf{1 0 0 . 0}$ \\
\hline
\end{tabular}

to the study section) is value relevant. Following prior research, we use the Ohlson (1995) model to test our hypotheses. Our objective is to test whether interim earnings and book values are associated with market values of equity (Hypothesis 1). Our secondary objective relevant to this section of the paper is to confirm prior findings in the literature that annual accounting information is associated with market values of equity. The unscaled Ohlson (1995) model is specified as follows:

$$
\mathrm{MVE}_{\mathrm{it}}=\alpha_{0}+\alpha_{1} \mathrm{BVE}_{\mathrm{it}}+\alpha_{2} \mathrm{EARN}_{\mathrm{it}}+\varepsilon_{\mathrm{it}}
$$

where $M V E_{i t}$ is the market value of equity (share price times number of shares outstanding) for firm $i$ measured 3 months after the reporting period $(t) ; B V E_{i t}$ is the book value of equity for firm $i$ at the end of the reporting period $(t), E A R N_{i t}$ is the net profit after tax for firm $i$ for the period under examination $(t)$, and $\varepsilon_{i t}$ is the error term.

Following Barth, Landsman and Lang (2008), Devalle et al. (2010), Hellstrom (2006) and Venter et al. (2014), we used a levels approach and winsorised all the variables at a $95 \%$ level to mitigate the effects of outliers in the sample (Barth et al. 2008). We recognise that size could have an effect on the inferences drawn from level specifications and scaled all our variables with number of shares 3 months after reporting date (see Barth \& Clinch 2009). A 3-month lag period was used to allow time for accounting information to be communicated to the public. Following Chen, Liu and Ryan (2008), Gow, Ormazabal and Taylor (2010) and Peterson (2009), we corrected for cross-sectional and time-series dependence in our data by clustering standard errors by firm and by year. Peterson (2009) argues that clustering standard errors on multiple dimensions (by firm and by year) will yield correct inferences and correct for correlated residuals in the dataset. The ordinary least squares regression (OLS) results are presented in Table 3 and discussed in the 'Hypothesis 1 ' section.

For robustness purposes, we estimated the OLS regressions for Equation 1 using share price data at the end of the reporting period instead of a 3-month lag to control for the possibility that the financial results could have been anticipated by shareholders before the reporting date. In addition, following the recommendation by Barth and Clinch (2009), we used an unscaled model of the Ohlson 
(1995) model and measured market value of equity with a 3-month lag after the interim and annual reporting periods as well as at the end of the reporting periods. Following Filip and Raffournier (2010), we also controlled for the possibility that loss-making firms could have different associations with market value of equity. The untabulated results of the robustness tests are reported in the 'Hypothesis 1' section.

\section{Changes in the value relevance of annual and interim financial statements over time}

We have two overall objectives related to Hypothesis 2. Firstly, to explore (we do not test this statistically) whether the value relevance of annual (see Hypothesis 2[a]) as well as interim (see hypothesis 2[b]), financial statements has changed from year to year during our sample period. Secondly, to explore whether interim information has higher value relevance than annual accounting information, or vice versa (see Hypothesis 2[c]). Following prior research, we used the Ohlson (1995) model and compared the adjusted $R^{2} S$ of regression results from year to year (see Collins et al. 1997; Devalle et al. 2010; Dontoh et al. 2004; Francis \& Schipper 1999; Goodwin \& Ahmed 2006; Hellstrom 2006). We used the Ohlson (1995) model as specified in Equation 1 and estimated it per year for annual and interim financial periods, respectively. As the OLS regressions results are estimated per year, serial correlation is not a concern; hence, we do not cluster standard errors per year. The combined OLS results for the value relevance of annual and interim financial statements over the sample period (using $R^{2} \mathrm{~S}$ as measure) are presented in Figure 1 and discussed in the 'Hypotheses 2(a), (b) and (c)' section. Year-to-year comparisons enabled us to evaluate Hypothesis 1(c).
For robustness purposes, we estimated the OLS regressions using share price data at the end of the reporting period instead of a 3-month lag. In addition, we used an unscaled model of the Ohlson (1995) model, and measured market value of equity with a 3-month lag after the interim and annual reporting periods as well as at the end of the reporting periods. The untabulated results are reported in the 'Hypotheses 2(a), (b) and (c)' section.

\section{Incremental value relevance of accounting information in} interim and annual financial statements

We follow two steps to test hypothesis 3 . The objective of the first step is to confirm whether accounting information, in general (published in annual and interim financial statements, using a pooled dataset), is value relevant to market participants. The objective of the second step is to evaluate the incremental value relevance of the changes in book value of equity and changes in earnings between interim and annual reporting dates.

In step 1, we run a pooled OLS regression for Equation 1. We argue that pooling data in this manner is similar to pooling data for large and small listed companies in one sample and thus similar to other studies that employed the Ohlson (1995) model. If the coefficients of $\alpha_{1}$ and $\alpha_{2}$ in Equation 1 are associated with market value, we can infer that accounting information in general is value relevant to shareholders. The results are presented in Table 4 and discussed in the 'Hypotheses 3' section.

The approach that we follow for step 2 is similar to that followed by Venter et al. (2014), where the authors tested whether headline earnings (i.e. non-IFRS earnings as measured based on certain criteria specified by the JSE) have

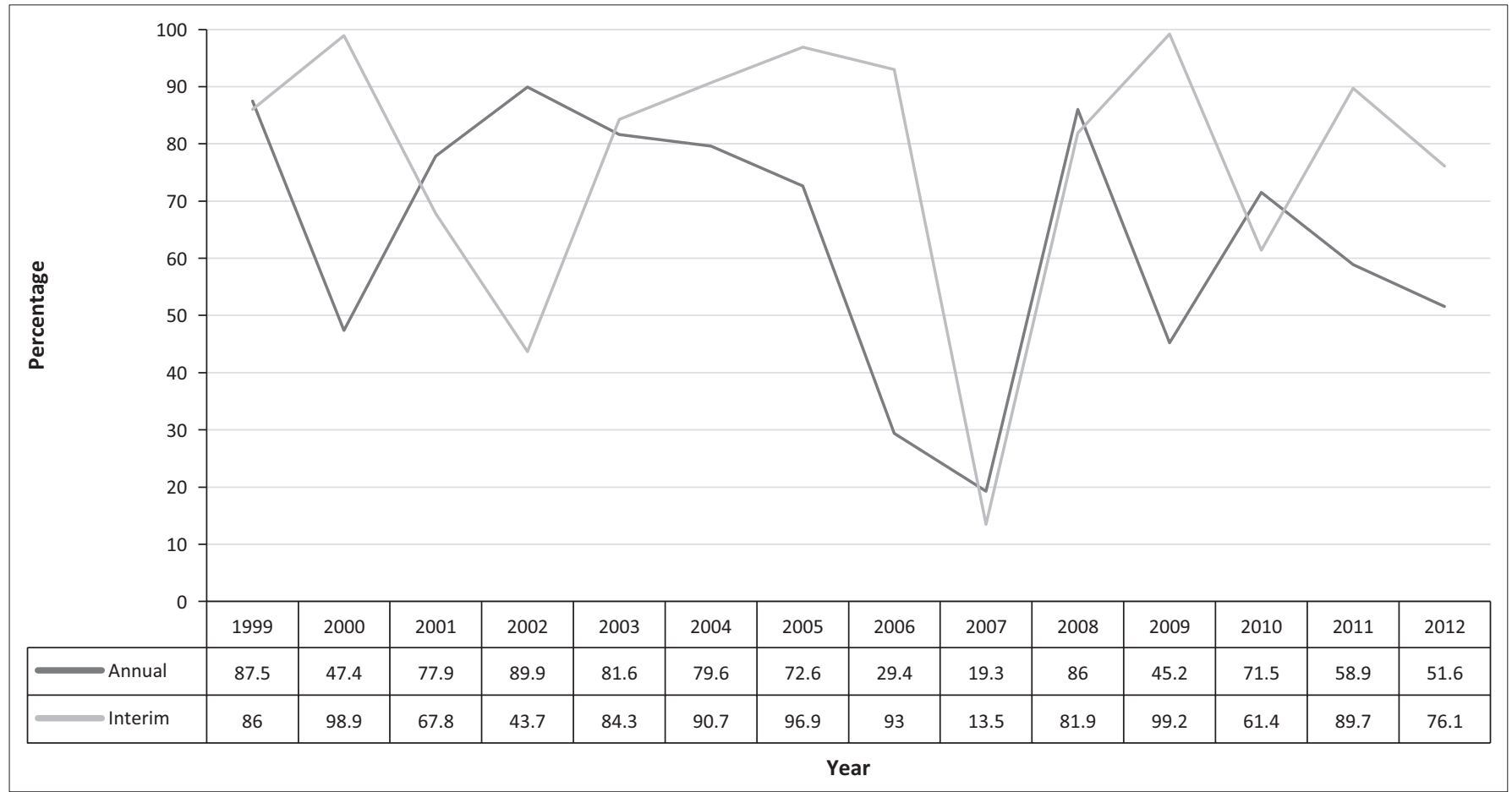

FIGURE 1: Exploratory evidence on Hypotheses 2(a), (b) and (c): Comparing adjusted $\mathrm{R}^{2} \mathrm{~s}$ of annual and interim regressions using the Ohlson model. 
incremental value relevance. Venter et al. (2014) focused on information available in annual financial statements. In this study, we argue that incremental comparisons are relevant to both book value of equity and earnings as measured at interim and annual reporting dates. We are interested in whether book values of equity measured at interim reporting data as well as the movement in book values of equity between interim and annual reporting dates are value relevant to shareholders. We are also interested in whether earnings at interim reporting date and the additional earnings that accrue to a company between interim and annual reporting dates are value relevant. We respecified the unscaled Equation 1 as follows:

$$
\begin{aligned}
\operatorname{MVE}_{\mathrm{it}}= & \alpha_{0}+\alpha_{1} \mathrm{BVE}_{-} \mathrm{INT}_{\mathrm{it}}+\alpha_{2} \mathrm{BVE}_{-} \mathrm{ADD} \mathrm{it}_{\mathrm{it}}+\alpha_{3} \mathrm{EARN}_{-} \mathrm{INT}_{\mathrm{it}} \\
& +\alpha_{4} \mathrm{EARN}_{-} \mathrm{ADD}_{\mathrm{it}}+\varepsilon_{\mathrm{it}}
\end{aligned}
$$

$\mathrm{MVE}_{\mathrm{it}}=\alpha_{0}+\alpha_{1} \mathrm{BVE}_{\mathrm{it}}+\alpha_{2} \mathrm{EARN}_{-} \mathrm{INT}_{\mathrm{it}}+\alpha_{3} \mathrm{EARN}_{-} \mathrm{ADD}_{\mathrm{it}}+\varepsilon_{\mathrm{it}}$

where $M V E_{i t}$ is the market value of equity 3 months after annual reporting date, $B V E_{-} I N T_{i t}$ is the book value of equity for firm $i$ at the end of the interim period $(t), B V E \_A D D_{i t}$ is the book value of equity for firm $i$ at the end of the annual reporting period $(t)$ minus $B V E_{-} I N T_{i t} ; E A R N_{-} I N T_{i t}$ is the net profit after tax for firm $i$ for the interim financial period under examination $(t), E A R N_{-} A D D_{i t}$ is the net profit after tax for firm $i$ for the annual period under examination $(t)$ minus $E A R N_{-} I N T_{i t}$, and other variables are as specified earlier. The sum of $B V E_{-} I N T_{i t}$ and $B V E_{-} A D D_{i t}$ represents the aggregate value of book value of equity at annual reporting date, $B V E_{i t}$. Similarly, the sum of EARN_INT ${ }_{i t}$ and EARN_ADD represents the aggregate value of earnings at the annual reporting date. Variance inflation factors (VIFs) for Equation 2a range between 1.44 and 5.56, and for Equation $2 \mathrm{~b}$ they range between 1.08 and 1.11. The VIFs are below 10, which is lower than the maximum acceptable level of 10 (Marquardt 1970). Therefore, multicollinearity is not a concern in our regression results. All variables are scaled with number of shares measured 3 months after the annual reporting period and standard errors are clustered per firm and per year. We evaluate whether $\alpha_{1}=\alpha_{2}$ in Equation $2 \mathrm{a}$, to consider the incremental value relevance of the book value of equity as measured at interim reporting date and the movement in book value of equity from the interim reporting date to the annual reporting date. Similarly, we evaluate whether $\alpha_{3}=\alpha_{4}$ in Equation $2 a$, and whether $\alpha_{2}=\alpha_{3}$ in Equation $2 b$, to consider the incremental value relevance of the earnings as measured at the interim reporting date and the additional earnings accrued between the interim and the annual reporting dates.

\section{Results \\ Descriptive statistics}

Panel A of Table 2 presents the descriptive statistics of the undeflated variables used in the Ohlson (1995) model for the annual data during the 14 years of observations. The currency is South African Rand (ZAR) for all the variables. The mean (median) market value of equity (MVE) 3 months after the annual reporting date is R11.3 billion (R821.7 million). The mean (median) for book value of equity (BVE) is R4.3 billion (R531.1 million), while the mean (median) for earnings $(E A R N)$ is $\mathrm{R} 957.7$ million (R73.8 million).

Panel B of Table 2 presents the descriptive statistics of the undeflated variables used in the Ohlson (1995) model for the interim data during the 14 years of observations. The mean (median) for MVE 3 months after the interim reporting date is R10.3 billion (R792.4 million). The mean (median) for BVE is R3.3 billion (R431.1 million); while the mean (median) for $E A R N$ is $\mathrm{R} 435.3$ million (R33.2 million).

Panel C of Table 2 presents the descriptive statistics of the undeflated variables used in the Ohlson (1995) model for the pooled dataset (i.e. where interim and annual information is combined into one dataset) during the 14 years of observations. The mean (median) for pooled market value of equity 3 months after the annual reporting date and interim reporting date is R10.8 billion (R808.7 million). The mean (median) for BVE is R3.8 billion (R449.5 million), while the mean (median) for earnings is R700.9 million (R48.2 million).

\section{Hypothesis 1}

Table 3 presents the results for testing whether interim (Hypothesis 1) and annual accounting information are value relevant. For interim data, BVE at interim reporting date is significant at $1 \%$ level, while net income at interim reporting

\begin{tabular}{|c|c|c|c|c|c|c|c|}
\hline Panel & Variable & $N$ & Mean $\dagger$ & Median $\dagger$ & $\begin{array}{l}\text { Standard } \\
\text { deviation } \dagger\end{array}$ & Minimum $\dagger$ & Maximum $\dagger$ \\
\hline \multirow{2}{*}{$\begin{array}{l}\text { A: Annual data: } M V E_{i t}=\alpha_{0}+\alpha_{1} B V E_{i t}+ \\
\alpha_{2} E A R N_{i t}+\varepsilon_{i t}\end{array}$} & $M V E_{i t}$ & 2296 & 11326583 & 821721 & 30541350 & 7492 & 160978445 \\
\hline & $B V E_{i t}$ & 2296 & 4340562 & 531162 & 10540020 & 3195 & 52791099 \\
\hline \multirow{3}{*}{$\begin{array}{l}\text { B: Interim data: } M V E_{i t}=\alpha_{0}+\alpha_{1} B V E_{i t}+ \\
\alpha_{2} E A R N_{i t}+\varepsilon_{i t}\end{array}$} & $M V E_{i t}$ & 2296 & 10383667 & 792432 & 27460095 & 7610 & 143252815 \\
\hline & $B V E_{i t}$ & 2296 & 3363676 & 431162 & 8626213 & 3902 & 44489006 \\
\hline & $E A R N_{i t}$ & 2296 & 435377 & 33291 & 1226058 & -188017 & 6482906 \\
\hline$\alpha_{2} E A R N_{i t}+\varepsilon_{i t}$ & $B V E_{i t}$ & 4592 & 3853591 & 449484 & 9671813 & 3195 & 52791099 \\
\hline & $E A R N_{i t}$ & 4592 & 700972 & 48274 & 2101769 & -225032 & 14284600 \\
\hline
\end{tabular}

TABLE 2: Descriptive statistics for the Ohlson (1995) model.

$\dagger, R^{\prime} 000$.

Note: The table sets out the descriptive statistics for all the undeflated variables used in the regression analysis for the sample period from 1999 to $2012 . \mathrm{MVE}_{\mathrm{it}}$ is the market value of equity (share price times the number of shares outstanding) of company $i$ in year $t 3$ months after the annual and interim reporting period. $B V E_{i t}$ is the book value of equity of company $i$ in year $t$ at annual and interim reporting dates. EARN $N_{i t}$ is the net profit after tax for company $i$ in year $t$ at annual and interim reporting dates. 
TABLE 3: OLS estimation with time and firm clustered standard errors of Equation 1: Hypothesis 1: $\left(M V E_{i t}=\alpha_{0}+\alpha_{1} B V E_{i t}+\alpha_{2} E A R N_{i t}+\varepsilon_{i t}\right)$.

\begin{tabular}{|c|c|c|c|c|c|}
\hline Variable & $N$ & $B V E_{i t}$ & $E{ }^{\prime} N_{i t}$ & F-statistic & Adjusted $R^{2}$ \\
\hline Annual data & 2296 & $0.661 *$ & $0.102 * *$ & 71.99** & $52.5 \%$ \\
\hline Additional test & - & 3.88 & 11.83 & - & - \\
\hline Interim data & 2296 & $0.014 * *$ & 0.021 & $72.77 * *$ & $88.2 \%$ \\
\hline Hypothesis 1 & - & 6.43 & 0.84 & - & - \\
\hline
\end{tabular}

Note: This table reports the OLS regression results (coefficient estimates and $t$-values) calculated by clustering firm and time-standard errors to control for both cross-sectional and time-series dependence of Equation 1. The two samples consist of annual and interim data, respectively. $M V E_{\text {it }}$ is the market value of equity 3 months after annual or interim reporting date scaled by the number of shares 3 months after annual or interim reporting date. $B V E_{i t}$ is the book value of equity at annual or interim reporting date. EARN $N_{i t}$ is the net profit after tax at annual or interim reporting date.

** and $*$ denote significance at the $1 \%$ and $5 \%$ level, respectively.

date is not significant. This could mean that shareholders place more reliance on BVE at interim reporting date, which is a cumulative figure than interim earnings which are due to change. Interestingly, the interim model exhibits a higher adjusted $\mathrm{R}^{2}$ of $88.2 \%$ than the annual model with an adjusted $\mathrm{R}^{2}$ of $52.5 \%$. These results show that BVE at interim reporting date is value relevant; however, net income at interim reporting date is not value relevant, hence Hypothesis 1 is partially supported. The results also show that both BVE and net income at annual reporting date are significantly associated with market values of equity, hence confirming prior findings (Barth et al. 2001; Kothari 2001).

Following Filip and Raffournier (2010), we run additional separate regressions to test the effect that loss-making companies have on the value relevance tests. The untabulated results show a significant increase in the adjusted $R^{2}$ of the annual data model to $88.8 \%$ compared with $52.5 \%$ for the model including negative earnings (as reported in Table 3). For the interim data, the adjusted $\mathrm{R}^{2}$ slightly increases to $88.3 \%$ for positive earnings only compared with $88.2 \%$ for the whole sample (see Table 3). This is not surprising because losses have been found to reduce the value relevance of earnings and therefore reduce the value relevance of the model containing negative earnings (Collins et al. 1997; Hayn 1995; Venter et al. 2014). A similar finding was observed in a study conducted by Filip and Raffournier (2010), where they found an increase in the explanatory power of the model when negative earnings were excluded from the analysis. They attribute this finding to the view that negative earnings are more transitory than positive earnings. The coefficients for BVE and EARN as reported in Table 3 remain qualitatively similar when loss-companies are excluded from the sample for both interim and annual reporting periods. The untabulated results of the additional robustness tests for Hypothesis 1 are qualitatively similar to those obtained in the main model and support the results presented in Table 3.

\section{Hypotheses 2(a), (b) and (c)}

Figure 1 reports the results of Hypothesis 2(a), namely that the association of annual earnings and book values of equity with share price has not changed over the sample period; and Hypothesis 2(b), namely that the association of interim earnings and book values of equity with share price has not changed over time. The darkest-shaded region represents the explanatory power of the annual yearly regressions, while the lightest-shaded region represents the explanatory power of the interim yearly regressions. The adjusted $R^{2}$ of the yearly regressions ranges between $19.3 \%$ (2007) and $89.9 \%$ (2002) for the annual data; and $13.5 \%$ (2007) and $98.9 \%$ (2000) for the interim data. The adjusted $\mathrm{R}^{2}$ of both models appear to be fluctuating throughout all the years under observation. A similar finding was observed by Thinggaard and Damkier (2008) that the value relevance of annual accounting information has not changed over the years. An interesting observation to note is that the explanatory power of the interim model is higher than the explanatory power of the annual model in 8 years out of a total of 14 years under observation, thus providing support for Hypothesis 2(c). Hypothesis 2(c) is also supported when we compare the adjusted $R^{2}$ of interim accounting information with the adjusted $\mathrm{R}^{2}$ of annual accounting information as presented in Table 3 (88.2\% compared with 52.5\%).

Interesting to note from the inspection of Figure 1 is that the explanatory power of the interim model was at its lowest in 2007 (13.5\%), as well as the explanatory power of the annual model was at its lowest in 2007 (19.3\%). We argue that this could have been because of the global financial and economic crisis that hit the world, including South Africa in December 2007 until mid-2009 (Steytler \& Powell 2010:3). This crisis led to a slower economic growth, combined with lower commodity prices and a slowdown in capital flows to developing countries. All these negative factors could have negatively affected earnings and book values of equity for JSE listed companies (Baxter). The crisis was so severe that the JSE stock exchange devalued by almost $20 \%$ and the Rand depreciated by almost 37\% against the US dollar during June/July 2008 (Viegi 2008). We argue that a devalued share price associated with decreased earnings for the period could have resulted in the drop in the explanatory power of both models. Following Badenhorst, Brummer and de Wet (2015), Devalle et al. (2010) and Gu (2007, we performed the Chow test (Chow 1960) to establish if there was a structural break in the relationship between market values of equity and interim and annual accounting information between the years 2005, 2006, 2007 and 2008.

The Chow test ( $p$-values) (untabulated) is significant at the $1 \%$ level for annual accounting information between the years 2005 to 2006, 2006 to 2007 and 2007 to 2008. This indicates that there was a structural break in the relationship between market values of equity and interim earnings and book values of equity during the above-mentioned years. The explanatory power decreased from $72.6 \%$ in 2005 to a low $29.4 \%$ in 2007 and further decreased to $19.3 \%$ in 2007. 
For interim data, the Chow test ( $p$-values) (untabulated) is not significant between the years 2005 and 2006 and it is positive and significant at the $1 \%$ level between the years 2006 and 2007. This indicates that there was a structural break in the relationship between market values of equity and interim earnings and book values of equity in 2007. The explanatory power of the interim regression decreased from $93 \%$ (2006) to a low $13.5 \%$ (2007) and subsequently increased to $81.9 \%$ (2008).

The untabulated results of the robustness tests are qualitatively similar to those obtained in the main model and support the results presented in Figure 1.

\section{Hypothesis 3}

Table 4 contains the results of the OLS pooled regression, testing whether accounting information published in annual and interim financial statements is value relevant (step 1 to test hypothesis 3). As our data are subject to cross-sectional and time-series dependence, we report results for the coefficient estimates and $t$-values that are calculated using firm and time-clustered standard errors (Chen et al. 2008; Gow et al. 2010; Peterson 2009). As expected, the coefficients of BVE and EARN are both positive and significant at the $1 \%$ level. The model exhibits a high explanatory power of $88.5 \%$ as measured by the adjusted $R^{2}$. These results show that accounting information in general, using one combined dataset for annual and interim reporting values, is value relevant as predicted in prior literature (see the Background to the study section).
Table 5 presents results of the OLS regression, testing the incremental value relevance of the changes in book values of equity and changes in earnings between interim and annual reporting dates (Equation 2a). The first coefficient of interest, $B V E \_A D D_{i t^{\prime}}$ is positive and significant at $5 \%$ level, while the second coefficient of interest, EARN_ADD ${ }_{i t^{\prime}}$ is positive and significant at $1 \%$ level. The coefficient of $B V E_{-}$ $I N T_{i t}$ is positive and significant, while the coefficient of $E A R N_{-} I N T_{\text {it }}$ is positive and not significant, suggesting that earnings which accrue to a company between interim and annual reporting periods are more value relevant than interim earnings. It appears as if shareholders place more emphasis on additional earnings than on earnings at interim reporting date. Table 6 presents results of the OLS regression for Equation $2 \mathrm{~b}$. The coefficient of $E A R N_{-} A D D_{i t}$ estimate $(0.086)$ is higher than the coefficient estimate (significant at $1 \%$ level) of EARN_INT ${ }_{i t}$ (0.037) (not significant), supporting the results found in Equation 2a, namely, that interim earnings is not value relevant to market participants. Overall, these results show that both $B V E_{-} I N T_{i t}$ and $B V E_{-}$ $A D D_{i t}$ are significantly associated with market values of equity.

For robustness purposes, we scaled all the variables with number of shares at reporting date and used an unscaled model where market value of equity is measured 3 months after reporting date, as well as at reporting date. The untabulated results of the OLS two-way clustered standard errors regressions for Equations $2 \mathrm{a}$ and $2 \mathrm{~b}$ are qualitatively similar to the main model, where all the variables are scaled by the number of shares 3 months after reporting date.

TABLE 4: OLS estimation with time and firm clustered standard errors of Equation 1: Hypothesis 3, step $1\left(M V E_{i t}=\alpha_{0}+\alpha_{1} B V E_{i t}+\alpha_{2} E A R N_{i t}+\varepsilon_{i t}\right)$.

\begin{tabular}{lllll}
\hline $\boldsymbol{N}$ & $B V E_{i t}$ & $E A R N_{i t}$ & F-statistic & ${\text { Adjusted } \boldsymbol{R}^{2}}$ \\
\hline 4592 & $0.151^{*}$ & $0.117^{*}$ & $1438.32^{*}$ & - \\
\hline
\end{tabular}

Note: This table reports the OLS regression results (coefficient estimates and $t$-values) calculated by clustering firm and time-standard errors to control for both cross-sectional and time-series correlation (Gow et al. 2010) of Equation 1. The sample consists of a pooled dataset (annual and interim data combined into one dataset) for annual and interim accounting data. MVE it is the market value of equity 3 months after annual and interim reporting date scaled by the number of shares 3 months after annual and interim reporting dates. $B V E_{i t}$ is the book value of equity at annual and interim reporting dates. $E A R N_{i t}$ is the net profit after tax at annual and interim reporting dates.

*, denotes significance at the $1 \%$ level.

TABLE 5: OLS estimation with time and firm clustered standard errors of Equation 2a: Hypothesis 3 , step $2\left(M V E_{i t}=\alpha_{0}+\alpha_{1} B V E_{-} I N T_{i t}+\alpha_{4} B V E_{-} A D D_{i t}+\alpha_{2} E A R N_{-} I N T_{i t}+\right.$ $\left.\alpha_{5} E A R N_{-} A D D_{i t}+\varepsilon_{i t}\right)$.

\begin{tabular}{|c|c|c|c|c|c|c|}
\hline$\underline{N}$ & $B V E_{-} I N T_{i t}$ & $B V E_{-} A D D_{i t}$ & $E A R N \_I N T_{i t}$ & $E A R N \_A D D_{i t}$ & F-statistic & Adjusted $R^{2}$ \\
\hline 2296 & $0.012^{*}$ & $0.074 * *$ & 0.066 & $0.074 * * *$ & $2749 * *$ & $37.9 \%$ \\
\hline- & $(2.49)$ & $(2.36)$ & (1.64) & (7.98) & - & - \\
\hline
\end{tabular}

Note: This table reports the OLS regression results (coefficient estimates and $t$-values) calculated by clustering firm and time-standard errors to control for both cross-sectional and time-series correlations (Gow et al. 2010) of Equation 2a. MVE is the market value of equity 3 months after annual reporting date scaled by the number of shares 3 months after annual reporting date. $B V E_{-} I N T_{\text {it }}$ is the book value of equity at interim reporting date scaled by the number of shares 3 months after interim reporting date. $B V E A D D$ is the book value of equity at annual reporting date minus $B V E_{-} I N T_{i t}$. $E A R N_{\_} I N T_{i t}$ is the net profit after tax at interim reporting date scaled by the number of shares 3 months after interim reporting date. EARN_ADD is the net profit after tax for the annual reporting period minus EARN_INT

$* * *, * *$ and $*$ denote significance at the $1 \%, 5 \%$ and $10 \%$ level, respectively.

TABLE 6: OLS estimation with time and firm clustered standard errors of Equation $2 \mathrm{~b}$ : Hypothesis 3 , step $2-$ additional analysis $\left(M V E_{i t}=\alpha_{0}+\alpha_{1} B V E_{i t}+\alpha_{2} E A R N_{-} I N T_{i t}+\right.$ $\left.\alpha_{5} E A R N \_A D D_{i t}+\varepsilon_{i t}\right)$.

\begin{tabular}{|c|c|c|c|c|c|}
\hline $\bar{N}$ & $B V E_{i t}$ & $E A R N_{-} I N T_{i t}$ & $E A R N_{-} A D D_{i t}$ & F-statistic & Adjusted $R^{2}$ \\
\hline 2296 & $6.001 *$ & 0.037 & $0.086 *$ & $1537 *$ & $44.5 \%$ \\
\hline - & $(5.37)$ & $(0.23)$ & (5.92) & - & - \\
\hline
\end{tabular}

Note: This table reports the OLS regression results (coefficient estimates and $t$-values) calculated by clustering firm and time-standard errors to control for both cross-sectional and time-series correlations (Gow et al. 2010) of Equation 2b. MVE it is the market value of equity 3 months after annual reporting date scaled by the number of shares 3 months after annual reporting date. $B V E_{\text {it }}$ is the book value of equity at annual reporting date scaled by the number of shares 3 months after interim reporting date. BV_ADD is the BVE at annual reporting date. EARN_INT is the net profit after tax at interim reporting date scaled by the number of shares 3 months after interim reporting date. EARN_ADD it is the net profit after tax for the annual reporting period minus $E A R N_{-} I N T_{i t .}$.

*, denotes significance at the $1 \%$ level. 


\section{Conclusion}

The overall objective of the study is to evaluate and compare the value relevance of annual and interim accounting information. The study examines the value relevance of interim accounting information and is, to the best of our knowledge, the first study to explore if this value relevance has changed over the sample period. In addition, this is the first study to evaluate whether accounting information (earnings and book values) published in interim and annual financial statements, respectively, has incremental value relevance. The sample consists of non-financial listed companies on the JSE over the period from 1999 to 2012. The JSE mandates companies to publish interim reports on a sixmonthly basis. The JSE is the largest stock exchange in Africa and has an efficient stock market (World Economic Forum 2015); thus, it provides a strong setting for testing the value relevance of accounting information that will be of interest to the global market.

Firstly, our results show that interim book values of equity are positively and significantly associated with market values of equity, while interim earnings are not significant. Secondly, the results provide exploratory evidence that the value relevance of both annual and interim earnings and the book values of equity have not changed over the years. In addition, the incremental evaluations show that additional BVE and earnings, which accrue to a company between interim and annual reporting date, are value relevant. The results do not provide support for the notion that interim earnings allow investors to pre-empt annual earnings (see Firth 1981; Rippington \& Taffler 1995) as it is not associated with market value of equity, whereas earnings that accrue to a company between interim and annual reporting dates have a positive association with market value of equity as measured at financial year end. The results are robust for various model specifications.

The findings will be of interest to managers when making disclosure decisions, as well as investors and financial analysts when analysing published accounting information. The findings will also be of interest to standard setters and regulatory bodies as the results show that earnings figures in interim financial statements are not associated with market value of equity. This is particularly interesting considering that IAS 34, Interim Financial Reporting, requires JSE listed companies to publish and distribute interim financial statements. The questions which the results of this study raise are as follows: Is the cost of preparing an interim report worth the perceived benefits? If interim earnings are not associated with market value of equity, why should companies continue doing so? Future research could possibly address these questions.

Future research is also needed to establish whether there are differences in the value relevance of interim accounting information prior to IFRS adoption (2005) and after IFRS adoption (2006), although the evidence presented in Figure 1 seems to indicate that the differences would be negligible.
In addition, future research could test the market reaction of interim earnings and BVE using a market return specification, similar to the research design of an event study. Finally, future research could conduct a similar study in countries where it is voluntary to prepare and publish interim financial reports or, alternatively, where it is mandatory to publish interim reports on a quarterly basis instead of a six-monthly basis.

\section{Acknowledgements Competing interests}

The authors declare that they have no financial or personal relationships that may have inappropriately influenced them in writing this article.

\section{Authors' contributions}

M.Z. was responsible for the overall article as primary and corresponding author. M.d.K. was responsible for the introduction and conclusion and supervision of all sections. J.O. supervised the article.

\section{References}

Alegria, C., McKenzie, G. \& Wolfe, S., 2009, 'Earnings announcements by UK companies: Evidence of extreme events?', The European Journal of Finance 15, 137-156. https://doi.org/10.1080/13518470802466261

Badenhorst, W.M., Brummer, L.M. \& de Wet, J.H., 2015, 'The value relevance of listed associates: A cross-country investigation', South African Journal of Accounting Research 30, 61-78.

Ball, R. \& Brown, P., 1968, 'An empirical evaluation of accounting income numbers', Journal of Accounting Research 6, 159-177. https://doi.org/10.2307/2490232

Barth, M.E., Beaver, W.H. \& Landsman, W.R., 2001, 'The relevance of the value relevance literature for financial accounting standard setting: Another view', Journal of Accounting and Economics 31, 77-104. https://doi.org/10.1016/S01654101(01)00019-2

Barth, M.E. \& Clinch, G., 2009, 'Scale effects in capital markets-based accounting research', Journal of Business Finance \& Accounting 36, 253-288. https://doi. org/10.1111/j.1468-5957.2009.02133.x

Barth, M.E., Landsman, W.R. \& Lang, M., 2008, 'International accounting standards and accounting quality', Journal of Accounting Research 46, 467-498. https://doi. org/10.1111/j.1475-679X.2008.00287.x

Baxter, R., 2009, 'The global economic crisis and its impact on South Africa and the country's mining industry', Challenges for monetary policy-makers in emerging markets, pp. 105-116, South African Reserve Bank, South Africa.

Beaver, W., 1968, 'The information content of annual earnings announcements', Journal of Accounting Research 6, 67-92. https://doi.org/10.2307/2490070

Biddle, G.C., Seow, G.S. \& Siegel, A.F., 1995, 'Relative versus incrémental information content', Contemporary Accounting Research 12, 1-23. https://doi.org/10.1111/ j.1911-3846.1995.tb00478.x

Brown, P. \& Niederhoffer, V., 1968, 'The predictive content of quarterly earnings', Journal of Business 41, 488-497. https://doi.org/10.1086/295141

Brown, S., Lo, K. \& Lys, T., 1999, 'Use of $R^{2}$ in accounting research: Measuring changes in value relevance over the last four decades', Journal of Accounting and Economics 28, 83-115. https://doi.org/10.1016/S0165-4101(99)00023-3

Cahan, S.F., Courtenay, S.M., Gronewoller, P.L. \& Upton, D.R., 2000, 'Value relevance of mandated comprehensive income disclosures', Journal of Business Finance \& Accounting 27, 1233-1365. https://doi.org/10.1111/1468-5957.00356

Chen, P. \& Zhang, G., 2007, 'How do accounting variables explain stock price movements? Theory and evidence', Journal of Accounting and Economics 43, 219-244. https://doi.org/10.1016/j.jacceco.2007.01.001

Chen, W., Liu, C., and Ryan, S., 2008, 'Characteristics of securirizations that determine the issuer's retention of the risks of the securitized assets', The Accounting Review 85, 1181-1215. https://doi.org/10.2308/accr.2008.83.5.1181

Chow, G.C., 1960, 'Tests of equality between sets of coefficients in two linear regressions', Econometrica 28, 591-605. https://doi.org/10.2307/1910133

Clarkson, P., Hanna, J.D., Richardson, G.D. \& Thompson, R., 2011, 'The impact of IFRS adoption on the value relevance of book value and earnings', Journal of Contemporary Accounting \& Economics 7, 1-17. https://doi.org/10.1016/j.jcae.2011.03.001

Collins, D.W., Maydew, E.L. \& Weiss, I.S., 1997, 'Changes in the value-relevance of earnings and book values over the past forty years', Journal of Accounting and Economics 24, 39-67. https://doi.org/10.1016/S0165-4101(97)00015-3 
Devalle, A., Onali, E. \& Magarini, R., 2010, 'Assessing the value relevance of accounting data after the introduction of IFRS in Europe', Journal of International Financial Management and Accounting 21, 85-119. https://doi.org/10.1111/j.1467-646X. 2010.01037.x

Dimitropoulos, P.E. \& Asteriou, D., 2008, 'The value relevance of financial statements and their impact on stock prices', Managerial Auditing Journal 21, 248-265.

Dontoh, A., Radhakrishan, S. \& Ronen, J., 2004, 'The declining value relevance of accounting information and non-information-based trading: An empirical analysis', Contemporary Accounting Research 21, 795-812. https://doi. org/10.1506/J6P4-2UYP-HFXY-RBT1

Filip, A. \& Raffournier, B., 2010, 'The value relevance of earnings in a transition economy: The case of Romania', The International Journal of Accounting 45, 77-103. https://doi.org/10.1016/j.intacc.2010.01.004

Firth, M., 1981, 'The relative information content of the release of financial results data by firms', Journal of Accounting Research 19, 521-529. https://doi. org/10.2307/2490878

Francis, J. \& Schipper, K., 1999, 'Have financial statements lost their relevance?', Journal of Accounting Research 37, 319-353. https://doi.org/10.2307/2491412

Gjerde, Ø., Knivsfla, K. \& Saettem, F., 2011, 'The value relevance of financial reporting in Norway 1965-2004', Scandinavian Journal of Management 27, 113-128. https://doi.org/10.1016/j.scaman.2010.08.001

Goodwin, J. \& Ahmed, K., 2006, 'Longitudinal evidence of earnings and intangible assets: Evidence from Australian firms', Journal of International Accounting, Auditing and Taxation 15, 72-91. https://doi.org/10.1016/j.intaccaudtax.2006. 01.005

Gow, I.D., Ormazabal, G. \& Taylor, D.J., 2010, 'Correcting for cross-sectional and timeseries dependence in accounting research', The Accounting Review. 85, 483-512. https://doi.org/10.2308/accr.2010.85.2.483

Gu, Z., 2007, 'Across-sample incomparability of R2s and additional evidence on value relevance changes over time', Journal of Business Finance \& Accounting 34(7-8), 1073-1098.

Hayn, C., 1995, 'The information content of losses', Journal of Accounting and Economics 20, 125-153. https://doi.org/10.1016/0165-4101(95)00397-2

Hellstrom, K., 2006, 'The value relevance of financial accounting information in a transition economy: The case of Czech Republic', European Accounting Review 15 325-349. https://doi.org/10.1080/09638180600916242

Holthausen, R. \& Watts, R., 2001, 'The relevance of value-relevance literature for financial accounting standard setting', Journal of Accounting and Economics 31 3-75. https://doi.org/10.1016/S0165-4101(01)00029-5

Johannesburg Stock Exchange (JSE), 2012, JSE listing requirements, JSE, Johannesburg.

Johannesburg Stock Exchange (JSE) Limited, 2014, Annual report, viewed 15 June 2015, from www.jsereporting.co.za/ar2014

Kothari, S.P., 2001, 'Capital markets research in accounting', Journal of Accounting and Economics 31, 105-231. https://doi.org/10.1016/S0165-4101(01)00030-1

Landsman, W. \& Maydew, E., 2002, 'Has the information content of quarterly earnings announcements declined in the past three decades?', Journal of Accounting Research 40, 797-808. https://doi.org/10.1111/1475-679X.00071

Lev, B. \& Zarowin, P., 1999, 'The boundaries of financial reporting and how to extend them', Journal of Accounting Research 37, 353-385. https://doi.org/10.2307/ 2491413

Liu, J. and Liu, C., 2007, 'Value relevance of accounting information in different stock market segments: The case of Chinese A-, B- and H-shares', Journal of Internationa Accounting Research 6, 55-81. https://doi.org/10.2308/jiar.2007.6.2.55
Marquardt, D.W., 1970, 'Generalized inverses, ridge regression, biased linear estimation, and nonlinear Estimation', Technometrics 12, 591-612. https://doi. org/10.2307/1267205

McNichols, M. \& Manegold, J., 1983, 'The effect of the information environment on the relationship between financial disclosure and security price variability', Journal of Accounting and Economics 5, 49-74. https://doi.org/10.1016/01654101(83)90005-8

Oberholster, J.G.I., 2014, 'The understanding and use of interim financial reports by individual shareholders of South African listed retail companies for investment decisions', Unpublished doctorate, University of Pretoria, Pretoria.

Ohlson, J., 1995, 'Earnings, book values and dividends in security valuation', Contemporary Accounting Research 11, 661-687. https://doi.org/10.1111/j.1911 3846.1995.tb00461.x

Opong, K.K., 1995, 'The information content of interim financial reports: UK evidence', Journal of Business Finance \& Accounting 22, 269-279. https://doi. org/10.1111/j.1468-5957.1995.tb00683.x

Peterson, M.A., 2009, 'Estimating standard-errors in finance panel datasets: Comparing approaches', The Review of Financial Studies 22, 435-480. https://doi. org/10.1093/rfs/hhn053

Prather-Kinsey, J., 2006, 'Developing countries converging with developed-country accounting standards: Evidence from South Africa and Mexico', The International accounting standards: Evidence from South Africa and Mexico', The International
Journal of Accounting 41, 141-162. https://doi.org/10.1016/j.intacc.2006. Journal 04.007

Rahman, A.R., Tay, T.M., Ong, B.T. \& Cai, S., 2007, 'Quarterly reporting in a voluntary disclosure environment: Its benefits, drawbacks and determinants', The International Journal of Accounting 42, 416-442. https://doi.org/10.1016/j. intacc.2007.09.006

Rippington, F.A. \& Taffler, R.J., 1995, 'The information content of firm financial disclosures', Journal of Business Finance and Accounting 22, 345-362. https://doi. org/10.1111/j.1468-5957.1995.tb00878.x

Shores, D., 1990, 'The association between interim information and security returns surrounding earnings announcements', Journal of Accounting Research 28, 164-181. https://doi.org/10.2307/2491221

Steytler, N. and Powell, D., 2010, 'The impact of the global financial crisis on decentralised government in South Africa', L'Europe en Formation 4, 149-172.

Taylor, R.G., 1965, 'A look at published interim reports', The Accounting Review 40, 89-96.

Thinggaard, F. \& Damkier, J., 2008, 'Has financial statement information become less relevant? Longitudinal evidence from Denmark', Scandinavian Journal of Management 24, 375-387. https://doi.org/10.1016/j.scaman.2008.06.001

Venter, E.R., Emmanuel, D. \& Cahan, S.F., 2014, 'The value relevance of mandatory nonGAAP earnings', Journal of Accounting, Finance and Business Studies 50, 1-24.

Viegi, N., 2008, The impact of the financial crisis in South Africa, viewed 20 April 2015, from www.ids.ac.uk/go/financial-crisis-impact

Vieru, M., Pertunen, J. \& Schadewitz, H., 2006, 'How investors trade around interim earnings announcements', Journal of Business Finance \& Accounting 33, 145-178. https://doi.org/10.1111/j.1468-5957.2006.01358.x

World Economic Forum, 2015, Global competitiveness report 2014-2015, viewed 14 June 2015, from http://reports.weforum.org/global-competitiveness-report2014-2015/economies/\#economy=ZAF

Yee, K., 2004, 'Interim reporting frequency and financial analyst expenditures', Journal of Business Finance \& Accounting 31, 167-198. https://doi.org/10.1111/j. 0306-686X.2004.00005.x 